\title{
Strategi Pemberdayaan Masyarakat di Masa Pandemi melalui Program Peduli Dampak Corona (APDC) di LAZ Dompet Dhuafa Cabang Malang
}

\author{
Muhamad Faiz Abudalisa \\ Universitas Islam Negeri Sunan Ampel Surabaya, Indonesia \\ faizabudalisa@gmail.com \\ M. Hafiar Baidlowi \\ Universitas Islam Negeri Sunan Ampel Surabaya, Indonesia \\ hafwie@gmail.com
}

\begin{abstract}
:
This study intends to provide a formulation of community empowerment strategies during the pandemic which is carried out by the Malang branch of the Dompet Dhu'afa zakat institution. So far, every zakat institution has focused programs on the community (not only mustahik), but the program is only sudden and not programmed. However, the community empowerment strategy carried out by Dompet Dhu'afa was very effective because it was followed by an accurate management pattern, proportional-based programs and economic development. This is important to research, considering that a community empowerment strategy has not been formulated which has become a national pilot in the midst of a weakening world economy. This research is a descriptive qualitative study with a phenomenological approach to social institutions. All data are primary and extracted based on interview and documentation guidelines, in the final stage it is presented after going through the triangulation process. From the results of this study, several important things were found, namely the implementation of the Aksi peduli Dampak Corona program (APDC) during the Covid-19 pandemic, namely: 1) fish farming in artificial ponds, a freshwater fish cultivation program managed directly by the surrounding community. using artificial pond media, 2) Empowered Farmers are farming activities in the form of local vegetables and fruits which are commodities in the Malang region. Which in turn is managed directly by the surrounding community and directly supervised by experts from planting, maintenance, harvesting, to marketing, 3) Animal husbandry is one of the Corona Impact Care Action movements, here Dompet Dhuafa East Java presents approximately 30 sheep to be managed by surrounding communities affected by this pandemic as well as the stock for distributing the Sacrificial Animal Spread program next year.
\end{abstract}

Keywords: Community empowerment, Covid-19, zakat institutions 


\section{Latar Belakang}

Hingga saat ini, efek pandemi Covid-19 (pandemi effect) masih dirasakan oleh masyarakat, terutama pelaku bisnis dari dataran mikro sampai makro. Dampaknya menjadi ganda, kepada pelaku usaha dan pangsa pasar dan masyarakat. Sekalipun pemerintah masih menekan dengan berbagai program bantuan langsung, namun bukan berarti kedepannya tidak ada luka yang harus diobati. Disitulah peran lembaga zakat sebagai jenis lembaga keungan filantropi Islam, telah banyak mengubah kelemahan menjadi kekuatan dan kemiskinan menjadi ketercukupan dengan tujuan yang diemban yakni menggeser status "mustahiq" menjadi "muzakki".

Pembatasan sosial yang saat ini diberlakukan untuk penanganan dan pencegahan Covid -19, berdampak pada terbatasnya aktivitas manusia yang menyebabkan terganggunya aktivitas ekonomi masyarakat. Hal ini berdampak terhadap sektor transportasi, pariwisata, perdagangan dan kesehatan. Tidak terlepas dari kinerja pertumbuhan ekonomi dari segi eksternal dan internal. Faktor dari segi ekternal mengambil alih oleh ekonomi global yang melambat, terlebih lagi tren penurunan di lima negara utama dunia yakni (Amerika Serikat, Tiongkok, Jepang, India dan Uni Eropa), kebijakan ekonomi populis, apalagi adanya pandemi Covid19 akan menjadi faktor penentu perekonomian 2020. Dampak negatif sangat berpengaruh pada kinerja perekonomian dan perdangangan diakibatkan Covid-19. ${ }^{1}$

Di Indonesia terdapat empat sektor yang terdampak akibat wabah Covid-19 yaitu rumah tangga, UMKM, korporasi, dan sektor keuangan. Rumah tangga menjadi sektor yang pertama terdampak, dan paling rentan mengalami kesulitan ekonomi, dan kesulitan pangan. Oleh karena itu, diperlukan berbagai upaya untuk membangun ketahanan ekonomi dan pangan keluarga di Tengah pendemik covid -19 ini. Menteri Koordinator Bidang Perekonomian Airlangga Hartarto mengungkapkan, Pemerintah Indonesia selalu menempatkan keamanan dan keselamatan masyarakat sebagai prioritas utama, di samping menyeimbangkan ketahanan ekonomi dalam menghadapi Covid-19. ${ }^{2}$

Terkait perkembangan ekonomi nasional terkini, pemerintah pun selalu mengawasi dampak dari penyebaran Covid-19 terhadap perekonomian, Pemerintah Indonesia telah mengambil beberapa kebijakan ekonomi untuk mengatasinya, yaitu; Paket Stimulus I (Februari

\footnotetext{
1 Shairul Ihsan Burhanuddin; Muhammad Nur Abdi, "Krisis Ekonomi Global dari Dampak Penyebaran Virus Corona (Covid-19)", AkMenn Jurnal Ilmiah, 17,1 (2020): 90-98.

2 Silpa Hanoatubun, "Dampak Covid-19 terhadap Perekonomian Indonesia", EduPsyCouns: Journal of Education, Psychology and Counseling, 2, 1 (2020): 146-153.
} 
2020), menguatkan perekonomian domestik melalui: (a) Akselerasi proses penyebaran pengeluaran modal (capital expenditure), penunjukkan pejabat perbendaharaan resmi, implementasi lelang, dan penyaluran bantuan sosial (bansos); (b) Transfer Dana Desa; dan (c) Ekspansi jumlah penerima manfaat Kartu Sembako. ${ }^{3}$

Cara lain yang cukup menarik adalah dengan gerakan program padat karya salah satu upaya mengatasi pengangguran ini adalah Program padat karya merupakan salah satu upaya untuk mengentaskan kemiskinan dan mengurangi pengangguran serta dapat memberikan kesempatan kerja bagi tenaga kerja penganggur, setengah penganggur, dan pencari nafkah utama keluarga yang ditujukan untuk meningkatkan kesejahteraan masyarakat. Jenis-jenis usaha yang dapat dikembangkan dalam kegiatan padat karya produktif lebih berorientasi pada kegiatan usaha yang bersifat ekonomi produktif dan berkelanjutan. ${ }^{4}$

Di sini Lembaga Amil Zakat Dompet Dhuafa Jawa Timur juga menggulirkan beberapa program sebagai solusi bagi masyarakat terdampak Coronavirus disease 2019 (Covid-19). Melakukan gerakan Aksi Peduli Dampak Corona (APDC), diantaranya program yang digulirkan yakni ketahanan pangan dan ekonomi dengan konsep padat karya. Program padat karya merupakan salah satu upaya untuk mengentaskan kemiskinan dan mengurangi pengangguran yang diakibatkan dari efek pandemi Covid-19, yang mana dapat memberikan kesempatan kerja bagi tenaga kerja pengangguran. ${ }^{5}$

Gerakan APDC diharapkan menjadi program dimana penerima manfaat dilibatkan untuk produktif, memiliki ketahanan pangan skala keluarga, serta kegiatan usaha yang bersifat ekonomi produktif dan berkelanjutan. Berdasarkan uraian diatas peneliti tertarik untuk melihat lebih jauh mengenai efektivitas program melalui gerakan Aksi Peduli Dampak Corona (APDC) LAZ Dompet Dhuafa dalam menciptakan ketahanan pangan dan ekonomi masyarakat di masa pandemi Covid- 19.

\footnotetext{
${ }^{3}$ Ihsanuddin, 9 Kebijakan Ekonomi Jokowi di Tengah Pandemi Covid-19: Penangguhan Cicilan hingga Relaksasi Pajak, dalam https://nasional.kompas.com/read/2020/03/26/07412441/9kebijakan-ekonomi-jokowi-di-tengah-pandemi-covid-19-penangguhan-cicilan?page=all diakses tanggal 23 Februari 2021.

${ }^{4}$ Lihat dalam Afni Zulfikifli; Fara Merian Sari; Prihati, "Pendampingan Masyarakat Ekowisata Mangrove Sungai Berjarah (MSB) Kayu Ara Permai melalui Kebijakan Padat Karya di Masa Pandemi Covid-19”, Community Empowerment, 6, 1(2021): 71-80.

5 Ixhsan Emrald Alamsyah, "Dompet Dhuafa-RRI Inisiasi Aksi Peduli Dampak Corona”, lihat dalam https://republika.co.id/berita/dunia-islam/wakaf/qgu0jm349/dompet-dhuafarri-inisiasiaksi-peduli-dampak-corona diakses tanggal 24 Februari 2021.
} 


\section{Metode Penelitian}

Penelitian ini mengambil mengambil lokasi di Desa Tawangsari Kecamatan Pujon Kabupaten Malang. Pemilihan tempat berada di atas tanah wakaf milik Yayasan Bumi Maringi Peni yang merupakan mitra dari Lembaga Amil Zakat Dompet Dhuafa Jawa Timur. Penelitian ini menggunakan jenis penelitian kualitatif deskriptif. Bogdan dan Taylor mendefinisikan penelitian kualitatif sebagai prosedur penelitian yang menghasilkan data deskriptif berupa kata-kata tertulis atau lisan dari orang-orang atau prilaku yang diamati. ${ }^{6}$

Sumber data dalam penelitian kualitatif deskriptif yaitu melalui wawancara dan dokumentasi. Teknik pengumpulan data yang digunakan dalam penelitian ini adalah 1) wawancara (interview), percakapan dilakukan dengan dua pihak, yaitu pewawancara (interviewer) yang mengajukan pertanyaan dan terwawancara (interview) yang memberikan jawaban atas pertanyaan itu. 7 2) dokumentasi, penggunaan dokumen sudah lama digunakan dalam penelitian sebagai sumber data karena dalam banyak hal dokumen sebagai sumber data dimanfaatkan untuk menguji, menafsirkan, bahkan untuk meramalkan. ${ }^{8}$

\section{Hasil dan Pembahasan}

\section{Gambaran Umum LAZ Dompet Dhuafa Jawa Timur}

Lembaga Amil Zakat (LAZ) Dompet Dhuafa adalah lembaga nirlaba milik masyarakat Indonesia yang berkhidmat mengangkat harkat sosial kemanusiaan kaum dhuafa dengan dana ZISWAF (Zakat, Infaq Shadaqah, Wakaf, serta dana lainnya yang halal dan legal dari perorangan, kelompok, perusahaan atau lembaga.) kelahirannya berawal dari empati kolektif komunitas jurnalis yang banyak berinteraksi dengan masyarakat miskin, sekaligus kerap jumpa dengan kaum kaya. Kemudian digagaslah manajemen galang kebersamaan dengan siapapun yang peduli kepada nasib dhuafa. Empat orang wartawan yaitu Parni Hadi, Haidar Bagir, S. Sinansari Ecip dan Eri Sudewo berpadu sebagai dewan pendiri lembaga independen Dompet Dhuafa Republika. ${ }^{9}$

\footnotetext{
${ }^{6}$ Moleong, Lexy J. Metodologi Penelitian Kualitatif, (Bandung: Remaja Rosdakarya, 2010), 4.

${ }^{7}$ Cik Hasan Bisri, Pilar-Pilar Penelitian Hukum Islam dan Pranata Sosial (Jakarta : Grafindo Persada, 2004), hlm. 56.

${ }^{8}$ Burhan Bungin, Penelitian Kualitatif : Komunikasi, Ekonomi, Kebijakan Publik, dan Ilmu Sosial lainnya (Jakarta : Kencana Prenada Media Group), hlm. 108.

${ }^{9}$ Mar'atus Sholikah; Suherman Rosyidi, "Peran Lembaga Amil Zakat Dompet Dhuafa dalam Memberdayakan Peternak Miskin di Bangkalan", Jurnal Ekonomi Syariah Teori dan Terapan, 5, 11(2018): 905-920.
} 
Awalnya adalah sebuah kebetulan, walau sebagai orang yang beriman, kita percaya bahwa tidak ada sebuah kebetulan. Semuanya sudah ditentukan oleh Allah SWT., Sang Maha Perekayasa. April 1993, Koran Republika menyelenggarakan promosi untuk surat kabar yang baru terbit itu di Stadion Kridosono, Yogyakarta. Disamping sales promotion untuk menarik pelanggan baru, acara di stadion itu juga dimaksudkan untuk menarik pelanggan baru, acara di stadion itu untuk menarik minat masyarakat Yogyakarta untuk membeli saham koran umum Harian Republika. ${ }^{10}$

Hadir dalam acara itu Pemimpin Umum atau Pemred Republika Parni Hadi, Da'i sejuta umat (alm) Zainuddin MZ dan Raja Penyanyi Dangdut H. Roma Irama dan awak pemasaran Republika. Memang acara itu dikemas sebagai gabungan antara dakwah dan entertainment. Turun dari panggung, rombongan Republika dari Jakarta diajak makan di restoran Bambu Kuning dan disitu bergabung teman-teman dari Corps Dakwah Pedesaan (CPD) di bawah pimpinan Ustadz Umar Sanusi dan binaan pegiat dakwah di daerah miskin Gunung Kidul, (alm) Bapak Jalal Mukhsin. Dalam berbincang- bincang sambil santap siang, pimpinan CDP melaporkan kegiatan mereka yang meliputi mengajar ilmu pengetahuan umum, ilmu agama Islam dan pemberdayaan masyarakat miskin. ${ }^{11}$ Jadi anggota CDP berfungsi all-round: guru, da'i sekaligus aktivis sosial.

Ketika parni Hadi bertanya bertanya berapa gaji atau honor mereka per bulan, kemudian mereka menjawab: "masing-masing menerima enam ribu rupiah sebulan." Kaget, tercengang, setengah tidak percaya. Lalu pimpinan Republika itu bertanya lagi: "darimana sumber dana itu ?" Jawaban yang diterima membuat hampir semua nanggota rombongan itu kehabisan kata- kata: "itu uang yang sengaja disisihkan oleh para Mahasiswa dari kiriman orangtua mereka." Seperti tercekik , Parni Hadi menukas: "saya malu, mohon maaf, sepulang saya dari Yogyakarta ini saya akan membuat sesuatu untuk membantu teman-teman." Zainuddin MZ juga menambahkan: "saya akan bantu carikan dana."

Mengapa kaget, tercekik dan segera bereaksi? Karena Rp. 6000,waktu itu jumlah yang kecil untuk ukuran Yogyakarta, apalagi untuk ukuran Jakarta, sangat-sangat kecil. Apalagi uang itu berasal dari upaya penghematan hidup mahasiswa. Peristiwa itulah yang menginspirasi lahirnya Dompet Dhuafa Republika. Dari penggalangan dana Internal, lalu Republika mengajak segenap masyarakat untuk ikut menyisihkan

\footnotetext{
10 Muhtadi, "Pengaruh Peran Lembaga Karya Masyarakat Mandiri Dompet Dhuafa dalam Pengelolaan Zakat untuk Kemandirian Penerima Manfaat Program”, Jurnal Ilmu Dakwah, 40, 1(2020): 48-52.

${ }^{11}$ Lihat dalam web lembaga zakat dompet dhuafa, https://zakat.or.id/tentang-kami/sejarah/ diakses tanggal 24 Februari 2021.
} 
sebagian kecil penghasilannya. Pada tanggal 2 Juli 1993, sebuah rubrik di halaman muka Harian Umum Republika dengan tajuk "Dompet Dhuafa" pun dibuka. Kolom kecil tersebut mengundang pembaca untuk turut serta pada gerakan peduli yang diinisiasi Harian Umum Republika. Tanggal ini kemudian ditandai sebagai hari jadi Dompet Dhuafa Republika. ${ }^{12}$

Rubrik "Dompet Dhuafa mendapat sambutan luar biasa, hal ini ditandai dengan adanya kemajuan yang signifikan dari pengumpulan dana masyarakat. Maka, muncul kebutuhan untuk memformalkan aktivitas yang dikelola Keluarga Peduli di Republika. Pada 4 September 1994, Yayasan Dompet Dhuafa Republika pun didirikan. Empat orang pendirinya adalah Parni Hadi, Haidar Bagir, Sinansari Ecip dan Erie Sudewo. Sejak itu Erie Sudewo ditunjuk mengawal yayasan Dompet Dhuafa dalam mengumpulkan dan menyalurkan dana ZISWAF dalam wujud aneka programn kemanusiaan, antara lain untuk kebutuhan kedaruratan, bantuan ekonomi, kesehatan dan pendidikan bagi kalangan dhuafa.

Profesionalitas Dompet Dhuafa kian terasah seiring meluasnya program kepedulian yang semula hanya bersifat lokal menjadi nasional, bahkan internasional. Tidak hanya berkhidmat pada bantuan dana bagi kalangan tak berpunya dalam bentuk tunai, Dompet Dhuafa juga mengembangkan bentuk program yang lebih luas seperti bantuan ekonomi, kesehatan, pendidikan dan bantuan berencana. ${ }^{13}$

\section{Program Dompet Dhuafa Jawa Timur}

LAZ Dompet Dhuafa Jawa Timur merupakan salah satu lembaga amil zakat yang berusaha memberikan pelayanan secara profesional yang berkaitan dengan pengumpulan, penyimpanan dan penjagaan pencatatan dan penyaluran atau distribusi harta zakat.

Lokasi proyek Dompet Dhuafa terus berkembang dan tidak lagi terbatas di pulau Jawa saja, akan tetapi meluas ke seluruh wilayah Indonesia bahkan mancanegara. Sehingga kegiatannya pun bergeser dari sebatas program sosial menjadi pengembangan sumber daya manusia dan ekonomi. Program- program Dompet Dhuafa dalam pengentasan kemiskinan melalui beberapa aspek, yaitu:

a. Program Ekonomi,

1) Kawasan Mandiri dan Berdaya

\footnotetext{
12 Yudi Yudiana, "the Implementation of PSAK 109 on Infaq Shadaqah Funds in Zakat Instituions (Study in DMC Dompet Dhuafa)", Iltizam Journal of Shariah Economic Research, 4, 2(2020): 16-35.

13 Shafwan Ismail; Sri Sudiarti; M. Ridwan, "Peranan Dompet Dhuafa Waspada dalam Pemberdayaan Masyarakat Miskin melalui Pengembangan Usaha Mikro Kecil (UMK) di Kota Medan", Kitabah: Jurnal Akuntansi dan Keuangan Syariah, 2, 2(2018): 247-276.
} 
Kawasan Desa Mandiri dan Berdaya merupakan program holistik yang dilakukan oleh Dompet Dhuafa baik melalui program pelayanan maupun pemberdayaan dengan melalukan intervensi kepada masyarakat di sebuah wilayah pada aspek ekonomi, pendidikan, kesehatan, dan lingkungan. Tujuan dari program Kawasan Mandiri dan Berdaya adalah untuk meningkatkan taraf ekonomi masyarakat, mengangkat potensi daerah, memperbaiki kualitas pendidikan dan kesehatan.

2) Kampung Ternak

Program Kampung Ternak, fokus untuk menghidupkan potensi masyarakat dhuafa melalui program peternakan. Melalui pemberdayaan dan pendampingan intensif pada peternak, peranakan (breeding), dan penyediaan jaringan pasar. Program ini diharapkan mampu meningkatkan harkat kaum dhuafa sebagai peternak sukses yang tentunya meningkatkan kesejahteraan mereka pula. Selain itu, program Dompet Dhuafa juga membantu menyediakan pasar bagi para peternak melalui Program Tebar Hewan Kurban.

3) Pedagang Tangguh

Program Pedagang Tangguh merupakan upaya memberdayakan masyarakat, dengan fokus pada pedangan bakso. Pembentukan program Pedagang Tangguh dilatarbelakangi oleh kepedulian dari Dompet Dhuafa terhadap kondisi para pedagang bakso skala mikro yang masih terbatas dalam aspek produksi, managerial dan pemasaran. Keterbatasan ini menjadikan mereka jauh tertinggal dan kalah kompetitif dibandingkan dengan pedagang lainnya. Melihat kondisi tersebut, Dompet Dhuafa berkomitmen untuk membantu memperkuat eksistensi para pedagang bakso agar tetap survive, mandiri, dan dipercaya oleh publik. Bentuk penguatan yang dilakukan yakni melalui bantuan modal usaha (1 set gerobak dorong dan sarana penunjang), penguatan kapasitas mitra serta pendampingan usaha regular selama satu tahun. Bentuk penguatan kapasitas yang dilakukan yakni melalui pelatihan pelatihan yang dapat menambah pengayaan dan pemahaman mitra mengenai aspek keamanan pangan strategi pengembangan wirausaha, pengelolaan keuangan dan penguatan kelembagaan lokal.

b. Program Pendidikan

1) Beasiswa Prestasi 
Program Beasiswa Prestasi merupakan program bantuan pendidikan yang diperuntukan dagi manasiwal mahasiswi dhuafa berprestasi. Latar belakang lahirnya program ini adalah bahwa banyak mahasiswal mahasiswi yang berprestasi secara akademik ataupun non akademik yang tidak mendapatkan fasilitas secara optimal untuk mengembangkan potensi, skill, dan kemampuannya, karena keterbatasan ekonomi dan latar belakang keluarga. Dompet Dhuafa Jawa Timur berkomitmen untuk bisa memberikan kontribusi dan memberikan dampak langsung kepada para generasi penerus bangsa Indonesia, yang sedang menempuh pendidikan tinggi untuk dapat mengembangkan potensi diri, skill, dan kompetensi lainnya dalam bingkai dan nilai-nilai akhlaq mulia dan luhur. Saat ini program Beasiswa Prestasi bekerjasama dengan PUSPAS (Pusat Pengelolaan Dana Sosial) Universitas Airlangga Surabaya.

2) Rumah Qur'an

Rumah Qur'an adalah program berantas buta aksara $\mathrm{Al}$ Quran, aktifitas didalamnya lebih difokuskan untuk mempelajari, membaca, menghafalkan dan sekaligus mengamalkan nilai -nilai yang terkandung dalam Al-Qur'an. $54 \%$ dari populasi umat Islam di Indonesia buta membaca Alquran (BPS, 2015). Menurut Gus Sholah, hanya 23\% muslim di Indonesia yang bisa bacar Al-Quran (tebuireng.online). Minat untuk membaca terutama membaca Al-Quran dikalangan sebagian anak usia sekolah (usia 13-18 tahun) semakin berkurang ini dikarenakan anak pada usia tersebut masih dalam pencarian jati diri, mereka juga masih mudah terpengaruh dengan lingkungan pergaulan teman-temannya. Dengan kesenangan mereka bermain-main mereka lupa akan kewajibannya sebagai pelajar yaitu belajar. Hal ini juga berdampak dengan kemalasan mereka untuk mempelajari AlQur'an, terutama dalam membacanya.

3) Sekolah Pelosok

Sekolah pelosok merupakan kawasan pendidikan islam terpadu yang diinisiasi oleh jejaring program bersama Dompet Dhuafa. Sekolah ini didirikan untuk memudahkan para warga yang tinggal di daerah pelosok agar tetap memperoleh pendidikan yang layak dan islami. Mulai dari belajar menghitung, membaca, mengaji, pendidikan agama islam semuanya diajarkan di sekolah ini.

4) Guru Hebat 
Program Guru Hebat, ialah program pembelajaran produktif bagi guru dalam berkarya menghasilkan media pengajaran berkualitas dan terus meningkatkan kualitas mutu melalui aktivitas pembinaan dan pendampingan. Kami menyadari meskipun guru-guru sudah berusaha semaksimal mungkin dalam KBM, masih ada keterbatasan pengembangan kualitas SDM. Tidak semua sekolah memiliki kemampuan yang sama dalam melengkapi dan memiliki alat peraga guna mendukung KBM. Disinilah perlunya melakukan upgrading softskill dan bimbingan untuk memunculkan media-media pembelajaran kreatif guna mendukung KBM yang lebih efektif.

5) Rumah Belajar

Program pendidikan berbasis pembelajaran formal dan non-formal yang pesertanya difokuskan bagi anak-anak dhuafa, namun juga untuk kegiatan belajar bagi masyarakat umum sekitar. Kegiatan belajar mengajar d ilaksanakan setiap hari pada waktu sore dengan melibatkan pengajar/fasolitator yang kompeten dibidangnya.

c. Program Sosial dan Dakwah

1) Layanan Mustahik

Lamusta (Layanan Mustahik) adalah program ujung tombak yang melayani secara langsung para mustahik yang dalam kondisi mendesak. Tidak sedikit orang yang mengeluhkan kesulitan hidupnya seraya berharap mampu menyelesaikan permasalahan mereka yang mendesak seperti kehabisan bekal (musafir), tunggakan SPP, menebus obat di Rumah Sakit, tunggakan kontrakan, usaha yang bangkrut, hutang yangjatuh tempo dan permasalah sejenis lainnya.

2) Sedekah Makan Siang

Jumlah penduduk miskin (penduduk dengan pengeluaran per kapita per bulan dibawah Garis Kemiskinan) di Indonesiamencapai 25,95 Juta orang $(9,8296)$. Sedangkan di Jawa Timur Jumlah penduduk miskin mencapai 4.332, 59 ribu jiwa (10,98\%). Makanadalah kebutuhan pokok bagi manusia, namun bagi mereka yang fakir mtskin makan menjadi persoalan sulit untuk ditemukan solusinya. Dompet huafa Jawa Timur mengajak para dermawan untuk mendukung gerakan berbagi makan siap saji bagi mereka yang tergolong fakir dan miskin di seluruh Jawa Timur.

3) Barzah

(Badan Pemulasaran Jenazah) Barzah, merupakan program 
layanan sosial Dompet Dhuafa bagi masyarakat baik dhuafa maupun umum yang membutuhkan unit transport mobil jenazah. Program ini tidak dipungut biaya alias Cuma-cuma. Adapun layanan program barzah adalah mengantarkan jenazah dari rumah sakit menuju rumah duka dan ataupun dari rumah duka domisili menuju rumah kampung halaman. Saat ini program Barzah berada di wilayah Banyuwangi.

4) Bina Rohani Pasien

Program Bimbingan Rohani Pasien (BRP) merupakan kegiatan bimbingan rohani melalui sentuhan-sentuhan agama kepada seluruh pasien, baik yang berada di rumah sakit maupun di rumah shelter. Kegiatan imbingan ini menjadi bagian integral dari bentuk pelayanan kesehatan, karena pada dasarnya setiap diri manusia terdapat kebutuhan dasar spiritual.

Bimbingan rohani lslam berperan sebagai pemberian bantuan kepada individu berdasarkan ajaran Islam agar individu mampu hidup selaras dengan ketentuan dan petunjuk Allah, sehingga dapat mencapai kebahagiaan dunia dan akhirat.

5) Bedah Rumah

Memiliki rumah layak huni adalah impian semua orang, namun tidak semua berkesempatan untuk mewujudkannya. Ada banyak alasan yang tenjadi penghalang terwujudkannya impian ini, diantaranya jauhnya akses kelokasi mukim, keterbatasan biaya dan lain sebagainya, bedah rumah hadir sebagai suatu bentuk pelayanan bagi masyarakat kurang mampu yang tidak memiliki rumah layak huni di wilayah Jawa Timur.

6) Yuk Rawat Masjid

Yuk Rawat Masjid merupakan program syiar dakwah dan layanan bersih masjid. Adapun paket layanan kebersihan yang dimaksudkan seperti membersihkan karpet, kamar mandi, lantai dalam maupun luar masjid, jendela dan fasilitasS lainya. Program yuk rawat masjid bagian dari gerakan cinta masjid, sehingga program ini diharapakan juga melibatkan masyarakat sekitar masjid. Program Yuk Rawat Masjid merupakan salah satu wujud nyata dari komitmen Dompet Dhuafa untuk membantu masyarakat Indonesia menerapkan perlaku hidup bersih dan sehat dalam kehidupan sehari-hari.

7) Ramadhan Mubarok 
Ramadhan Mubarak merupakan program eventual, syiar dan layanan yang dilaksanakan pada bulan suci Ramadhan, adapun program Ramadhan yang dimaksud sebagai berikut:

a) PROGRAM CERIA (Canda Bersama Yatim), merupakan program eventual santunan, buka bersama, dongeng dan rihlah bersama adik-adik yatim.

b) PROGRAM KALDU (Kado Lebaran Dhuafa), merupakan program santunan pemberian bingkisan berupa sembako dan pakai baru bagi warga kurang mampu.

c) PROGRAM ABANG (Ngaji Bareng Dai Kondang), merupakan program tabligh syiar dakwah bersama ustadz kondang seperti Ustadz Abdus Shomad, Abdullah Gymnastiyar, Bactiar Nastir, Hendy Bone, Heru Kusumahadi, Naruto (Marzuki Imran) Salim Fillah, Zaidul Akbar dan lain-lain.

d)

PROGRAM FITRAH (Tebar Zakat Fitrah), merupakan program sebar zakat fitrah ke pelosok daerah dan ataupun ke lokasi binaan Dompet Dhuafa Jawa Timur.

e) PROGRAM PAMAN (Pesantren Ramadhan Bagi Para Pensiunan), merupakan syiar dakwah dan pembelajaran produktif khusus tentang agama islam yang pesertanya berasal dari anggota pensiunan.

d. Program Kemanusiaan

1) Respon Bencana

Indonesia menjadi negara yang paling rawan terhadap bencana di dunia berdasar data yang dikeluarkan oleh Badan Perserikatan Bangsa-Bangsa untuk, Strategi Internasional Pengurangan Risiko Bencana (UN-ISDR). Tingginya posisi Indonesia ini dihitung dari jumlah manusia yang terancam risiko kehilangan nyawa bila bencana alam terjadi. Sejak 1 Januari hingga 25 Oktober 2018, Indonesia telah mengalami 1999 kejadian bencana dengan 3548 korban jiwa.

2) Volunteer

Dompet Dhuafa Volunteer merupakan wadah bagi orang-orang yang tergerak dalam misi kemanusiaan dan membantu kegiatan-kegiatan pemberdayaan masyarakat secara sukarela. Tujuan dari Dompet Dhuafa volunteer adalah menciptakan komunitas relawan berbasis dukungan masyarakat untuk gerakan kemanusiaan dan kampanye zakat melaui program-program yang dilaksanakan oleh Dompet Dhuafa. Persyaratan untuk menjadi bagian dari Dompet 
Dhuafa Volunteer hanya cukup dengan memiliki kesediaan mendukung dan bergerak dengan tulus pada setiap misi kemanusiaan yang dilakukan bersama Dompet Dhuafa.

e. Program Social Enterprise

Sosial Enterprise merupakan kegiatan bisnis sosial yang bekerjasama dengan mitra strategis program dimana hasil keuntungan dari bisnis tersebut digunakan kembali untuk pembiayaan kegiatan sosial. Adapun kegiatan bisnis social yang dimiliki oleh Dompet Dhuafa Jawa Timur adalah Home Industri Tahu, Wirausaha Peternakan, Minimarket-Warung Sehat, dan usaha-usaha lainya yang berpeluang untuk menghasilkan profit bagi program social enterprise. ${ }^{14}$

\section{Program APDC Dompet Dhuafa Jawa Timur}

Dompet Dhuafa Jawa timur melakukan gerakan Aksi Peduli Dampak Corona (APDC) Dompet Dhuafa memiliki Sejumlah program yang digulirkan oleh Dompet Dhuafa Jawa Timur sebagai solusi bagi masyarakat terdampak Coronavirus disease 2019 (Covid-19). Gerakan APDC diinisiasi oleh wartawan senior, bapak Parni Hadi yg juga merupakan pendiri serta Pembina Dompet Dhuafa. Program ini digalakan sebagai solusi bagi masyarakat terdampak Coronavirus disease 2019 (Covid-19), di antara program yang digagas yakni ketahanan pangan dan ekonomi dengan konsep padat karya dengan tujuan pemberdayaan petani atau masyarakat yang terdampak krisis pandemi covid-19. ${ }^{15}$ Program padat karya ini merupakan salah satu upaya untuk mengurangi pengangguran melalui pembangunan sarana maupun prasarana pendukung untuk memperlancar roda perekonomian, khususnya di daerah pedesaan yang masih tertinggal.

Namun demikian, harus tetap memperhatikan peningkatan produktivitas dari program yang jalankan, agar mampu bersaing sebagai salah satu alternatif pelaksanaan konstruksi, baik dalam keadaan krisis maupun dalam keadaan ekonomi normal. Untuk itu perlu dilakukan pengukuran untuk mengetahui tingkat produktivitasnya. layak usaha, layak berkembang dan layak lingkungan, dan dikemudian hari dapat mewujudkan tenaga kerja yang profesional dan berkompetensi. Dalam

\footnotetext{
14 "Gerakan Budidaya Kolam Buatan (Budi Kolbu) Aksi Peduli Dampak Corona Dompet Dhuafa Jawa Timur", dalam http://dompetdhuafa.org/id/berita/detail/Gerakan-Budidaya-Kolam-Buatan-Budi-Kolbu--Aksi-Peduli-Dampak-Corona-Dompet-Dhuafa-Jawa-Timur diakses tanggal 24 Februari 2021.

15 Lihat dalam http://www.dompetdhuafa.org/id/berita/detail/Langkah-Konkret-APDC-Kolaborasi-Dompet-Dhuafa-dan-Kelompok-Darul-Arqam-Panen-2000-Kg-Ikan-Gurame diakses tanggal 24 Februari 2021.
} 
program APDC yang dilaksanakan di desa tawang Sari, kecamatan Pujon, kabupaten Malang yang berada di atas tanah wakaf dari Yayasan BMP ini, mempekerjakan warga yang berada di sekitar BMP yang sebelumnya mengalami PHK akibat pandemi. Di dalam gerakan APDC ini ada 3 program padat karya yang digalakan:

\section{BUDIKOLBU}

(BUDIKOLBU) Budidaya Ikan Dalam Kolam Buatan, merupakan program budidaya ikan air tawar seperti ikan lele dan ikan nila yang dikelola langsung oleh masyarakat sekitar menggunakan media kolam buatan. BUDIKOLBU ini sendiri bertujuan untuk melatih kepada warga sekitar supaya produktif dan memiliki ketahanan pangan skala keluarga. Cara kerja BUDIKOLBU sendiri adalah dengan menyediakan lahan cukup untuk dibuatkannya kolam buatan atau semi permanen yang kita mudah menyebutnya kolam terpal, di susun sedemikian rupa dan layak untuk dijadikan sarana tempat tinggal ikan air tawar.

Dalam kegiatan ini masyarakat sekitar mendapatkan pelatihan bagaimana cara merawat dan mengelola ikan kecil hingga ikan layak panen, dengan tujuan masyarakat disini dapat belajar dan mengaplikasikannya di tanah mereka sendiri sebagai ketahanan pangan dimasa pandemi ini khususnya.

2. Tani Berdaya

Tani Berdaya adalah kegiatan bertani berupa sayuran dan buahbuahan lokal yang menjadi komoditas di wilayah Malang. Yang pada kelanjutannya dikelola langsung oleh masyarakat sekitar dan diawasi langsung oleh pakarnya mulai penanaman, perawatan,panen, hingga pemasaran. Tani berdaya ini memiliki potensi sangat besar kepada masyarakat sekitar, dimana lebih dari 50\% masyarakat Jawa Timur memiliki mata pencaharian sebagai petani.

Aktifitas dalam program ini adalah, masyarakat bias langsung konsultasi tentang bagaimana perawatan tanaman sehingga dapat menghasilkan yang terbaik dan memiliki nilai jual yang mahal dipasaran. Selain konsultasi, tani berdaya juga memberi kesempatan untuk masyarakat mengelola langsung dan menjualnya langsung kepada konsumen melalui platform Dompet Dhuafa Jawa Timur dengan harga pasar dimana para petani tidak lagi khawatir dan kebingungan atas harga atau stok pemasaran yang dalam masa pandemi ini sangat sulit. Tujuan dari program ini tidak lain adalah untuk lebih mudah masyarakat dalam mengelola dan memasarkan hasil tani mereka kepada konsumen tanpa khawatir penumpukan barang dipasar yang mengakibatkan harga jual hasil tani mereka murah. 
3. Peternakan

Peternakan merupakan salah satu gerakan Aksi Peduli Dampak Corona, disini dompet Dhuafa Jawa Timur menghadirkan kembali kegiatan peternakan yang dulunya sempat berhenti karena sudah tidak ada pengelola serta pasokan hewan ternak itu sendiri. Disini Dompet Dhuafa jawa Timur menghadirkan kurang lebih 30 ekor domba untuk dikelola oleh masyarakat sekitar yang terdampak dalam pandemi ini serta sebagai stok pendistribusian program Tebar Hewan Kurban tahun depan.

Program ini memiliki potensi cukup besar dimana harga jual domba cukup mahal serta sarana untuk mencari bahan pakan hewan ternak itu sendiri sangat mudah, sehingga sangat memudahkan pengelola untuk merawat hewan ternak tersebut. Dalam kegiatan ini setidaknya sudah melibatkan 4 masyarakat sekitar untuk ikut andil merawat dan mengelola hewan ternak tersebut. Kebermanfaatan disini sangat jelas mereka bisa mengerjakan tugas kandang disela sela pekerjaan mereka yang dimasa pandemi ini tak lagi dapat diutamakan. ${ }^{16}$

\section{Efektifitas Gerakan Aksi Peduli Dampak Corona terhadap Pemberdayaan Petani}

Lokasi atau wilayah yang digunakan untuk penelitian pelaksanaan magang wakaf berbasis Riset berada di desa Tawangsari kecamatan Pujon kabupaten Malang. Secara keseluruhan dari kondisi wilayah BMP berpotensi untuk dapat meningkatkan perekonomian masyarakat yang terdampak pandemi. Yayasan BMP merupakan tanah wakaf yang sebelumnya milik pak Parni Hadi, selaku pendiri Dompet Dhuafa, pemilik tanah seluas 3 hektare, kemudian selanjutnya di untuk dikelola menjadi pesantren Fathussalam. Dan pengelola tanah sisa dari 3 hektare yang nantinya bakal di wakafkan semua untuk pengembangan dan kebutuhan pengembangan.

Gerakan Aksi Peduli Dampak Corona ini menjadi program yang sangat berpengaruh langsung kepada mustahik, dimana pada masa pandemi ini khususnya banyak masyarakat sekitar yang notabene pekerjaan mereka sangat bergantung dengan khalayak ramai, sehingga pendapatan mereka kini sering menipis hingga tak jarang mereka harus

16 Hani Fadilah, “APDC Dompet Dhuafa Ajak Mustahik Jadi Produktif”, dalam https://rri.co.id/madiun/sosial/899321/apdc-dompet-dhuafa-ajak-mustahik-jadi-

produktif?utm_source=news_main\&utm_medium=internal_link\&utm_campaign=General\%20C ampaign diakses tanggal 25 Februari 2021. 
rela kehilangan pekerjaan mereka satu satunya. ${ }^{17}$

Dalam program Aksi Peduli Dampak Corona di Dompet Dhuafa Jawa Timur ini, program ini fokus pada ketahanan pangan dan ekonomi dengan konsep padat karya multiguna. Dimana dalam tahap awal program ini masih terfokus pada kegiatan di bidang perikanan BUDIKKOLBU (budidaya ikan dalam kolam buatan), pertanian (Tani Berdaya), peternakan domba. Program ini cukup membantu masyarakat sekitar dalam hal alternatif pengganti pekerjaan yang sempat menjadi pokok sumber penghasilan mereka. Tidak sedikit dari mereka bersyukur dengan adanya gerakan APDC ini, mereka dapat ikut serta terlibat dalam pengelolaan dan kebermanfaatan dari program yang terdapat didalamnya.

Kriteria yang ditekankan dalam program APDC di Dompet Dhuafa Jawa Timur bukan hanya sekedar masyarakat yang ingin melakukan kegiatan padat karya multiguna saja, tetapi Dompet Dhuafa juga menilai dari kesungguhan dan komitmen masyarakat yang akan menjalankan program APDC tersebut. Karena salah satu indikator keberhasilan program ini juga bergantung pada kesungguhan dan kegigihan masyarakat dalam mengelola dan mengembangkan modal dan ilmu yang diberikan, termasuk pula komitmen untuk tidak menjadikannya modal konsumtif yang pada akhirnya akan putus ditengah jalan.

\section{Kesimpulan}

Berdasarkan uraian diatas yang penulis teliti dan rangkum, maka penulis mengambil beberapa kesimpulan yang terkalit tentang "Efektifitas Program Aksi Peduli Dampak Corona (APDC) Lembaga Dompet Dhuafa Jawa Timur Dalam Pemanfaatan Tanah Wakaf Yayasan Bumi Maringi Peni Untuk Pemberdayaan Petani Selama Pandemi yang mengalami PHK dan membuat warga mengalami kesulitan dalam segi ekonomi.

Pelaksanaan program Aksi Peduli Dampak Corona (APDC) di masa pandemi covid- 19 yang dilakukan oleh LAZ Dompet Dhuafa Jawa Timur Di Desa Tawangsari Kecamatan Pujon Kabupaten Malang yaitu ada 3 program padat karya yang digalakan: 1) Budidaya Ikan Dalam Kolam Buatan (BUDIKOLBU), merupakan program budidaya ikan air tawar yang dikelola langsung oleh masyarakat sekitar menggunakan media kolam buatan, 2) Tani Berdaya adalah kegiatan bertani berupa sayuran dan buah-buahan lokal yang menjadi komoditas di wilayah Malang. Yang pada kelanjutannya dikelola langsung oleh masyarakat sekitar dan

17 Aam lamet Rusydiana; Hasna Maliha; Salman al-Parisi, "Efficiencymeasurement of Zakat Institution Program: Case Study Dompet Dhuafa Indonesia", IJIBE: International Journal of Islamic Business Ethics, 1,1(2018): 28-43. 
diawasi langsung oleh pakarnya mulai penanaman, perawatan,panen, hingga pemasaran, 3) Peternakan merupakan salah satu gerakan Aksi Peduli Dampak Corona, Di sini Dompet Dhuafa Jawa Timur menghadirkan kurang lebih 30 ekor domba untuk dikelola oleh masyarakat sekitar yang terdampak dalam pandemi ini serta sebagai stok pendistribusian program Tebar Hewan Kurban tahun depan.

\section{Daftar pustaka}

Bisri, Cik Hasan. Pilar-Pilar Penelitian Hukum Islam dan Pranata Sosial. Jakarta : Grafindo Persada, 2004.

Bungin, Burhan. Penelitian Kualitatif : Komunikasi, Ekonomi, Kebijakan Publik, dan Ilmu Sosial lainnya. Jakarta : Kencana Prenada Media Group, 2017.

Burhanuddin, Shairul Ihsan; Muhammad Nur Abdi, "Krisis Ekonomi Global dari Dampak Penyebaran Virus Corona (Covid-19)", AkMenn Jurnal Ilmiah, 17,1 (2020).

Hanoatubun, Silpa. "Dampak Covid-19 terhadap Perekonomian Indonesia", EduPsyCouns: Journal of Education, Psychology and Counseling, 2, 1 (2020).

Ismail, Shafwan; Sri Sudiarti; M. Ridwan, "Peranan Dompet Dhuafa Waspada dalam Pemberdayaan Masyarakat Miskin melalui Pengembangan Usaha Mikro Kecil (UMK) di Kota Medan", Kitabah: Jurnal Akuntansi dan Keuangan Syariah, 2, 2(2018).

Moleong, Lexy J. Metodologi Penelitian Kualitatif. Bandung: Remaja Rosdakarya, 2010.

Muhtadi, "Pengaruh Peran Lembaga Karya Masyarakat Mandiri Dompet Dhuafa dalam Pengelolaan Zakat untuk Kemandirian Penerima Manfaat Program", Jurnal Ilmu Dakwah, 40, 1(2020).

Rusydiana, Aam Slamet; Hasna Maliha; Salman al-Parisi, "Efficiencymeasurement of Zakat Institution Program: Case Study Dompet Dhuafa Indonesia", IJIBE: International Journal of Islamic Business Ethics, 1,1(2018).

Sholikah, Mar'atus; Suherman Rosyidi, "Peran Lembaga Amil Zakat Dompet Dhuafa dalam Memberdayakan Peternak Miskin di Bangkalan", Jurnal Ekonomi Syariah Teori dan Terapan, 5, 11(2018).

Yudiana, Yudi. "the Implementation of PSAK 109 on Infaq Shadaqah Funds in Zakat Instituions (Study in DMC Dompet Dhuafa)", Iltizam Journal of Shariah Economic Research, 4, 2(2020).

Zulfikifli, Afni; Fara Merian Sari; Prihati, "Pendampingan Masyarakat Ekowisata Mangrove Sungai Berjarah (MSB) Kayu Ara Permai 
melalui Kebijakan Padat Karya di Masa Pandemi Covid-19", Community Empowerment, 6, 1(2021).

Mochammad Rizzqi Aladib, Wawancara (Malang, 20 Oktober 2020).

Ali Khamdan, Wawancara, (Malang, 29 Oktober 2020).

https://zakat.or.id/tentang-kami/sejarah/ 